\title{
Teaching in higher education in nursing: an integrative literature review
}

\author{
Docência no ensino superior em enfermagem: revisão integrativa de literatura
}

Enseñanza en la educación superior en enfermería: revisión integradora de literatura

\author{
Daniele Delacanal Lazzaria \\ Jussara Gue Martini ${ }^{\mathrm{b}}$ \\ Juliano de Amorim Busanac
}

DOl: $\quad$ http://dx.doi.org/10.1590/19831447.2015.03.49670

\footnotetext{
a Programa de Pós-Graduação em Enfermagem. Florianópolis, Santa Catarina, Brasil.

b Universidade Federal de Santa Catarina (UFSC). Departamento de Enfermagem. Florianópolis, Santa Catarina, Brasil.

'Prefeitura Municipal de Navegantes. Navegantes, Santa Catarina, Brasil.
}

\section{ABSTRACT}

Objective: to analyze the knowledge produced about teaching in higher education in nursing.

Method: Integrative literature review of full articles available on the LILACS, SciELO, BDENF and ERIC databases, through the descriptors "nursing faculty" and "practices of nursing faculty" and keywords "Teaching in nursing" or "Education in nursing" and "Nursing professors" and "Teaching knowledge" in Portuguese, English or Spanish, published from January 2008 to November 2013.

Results: 31 articles were identified. The data led to the following thematic categories: Training for faculty, Conflict of roles: being a nurse and being a teacher and Organization of the teaching work.

Conclusions: it was found that there are numerous gaps in understanding the teaching activity in nursing. The concerns identified may offer help for understanding the teaching world and conceptions about being a teacher in nursing.

Keywords: Faculty, nursing. Nursing faculty practice. Teaching.

\section{RESUMO}

Objetivo: analisar o conhecimento produzido sobre docência no ensino superior em enfermagem.

Método: revisão integrativa de literatura de artigos completos disponíveis nas bases de dados LILACS, SciELO, BDENF e ERIC, por meio dos descritores "docentes de enfermagem" $e$ "prática do docente de enfermagem" e das palavras-chave "docência em enfermagem" ou "ensino em enfermagem" $e$ "professores de enfermagem" $e$ "saberes docentes", em português, inglês ou espanhol, publicados no período de janeiro de 2008 a novembro de 2013.

Resultados: foram identificados 31 artigos. Os dados originaram as seguintes categorias temáticas: Formação para a docência, Conflito de papéis: ser enfermeiro e ser professor e Organização do trabalho docente.

Conclusões: constatou-se que existem inúmeros hiatos para compreensão da atividade docente na enfermagem. As preocupações identificadas podem oferecer subsídios para a compreensão do universo docente e as concepções sobre ser professor na enfermagem. Palavras-chave: Docentes de enfermagem. Prática do docente de enfermagem. Ensino.

\section{RESUMEN}

Objetivo: analizar el conocimiento producido sobre la enseñanza en la educación superior en enfermería.

Método: revisión integradora de artículos completos de la literatura disponible en LILACS, SciELO, BDENFy ERIC través de los descriptores" docentes de enfermería" $y$ " práctica del docente de enfermería" y las palabras clave "enseñanza en enfermería" 0 "educación en enfermería" $y^{\prime \prime}$ profesores de enfermería" $y$ "conocimiento enseñanza" en portugués, inglés o español, publicados entre enero de 2008 y noviembre de 2013.

Resultados: 31 artículos fueron identificados. Los datos produjeron las siguientes categorías: Formación para docencia, Conflicto de los roles: ser enfermera y ser profesor y Organización del trabajo docente.

Conclusiones: se encontró que existen numerosas lagunas en la comprensión de la actividad docente en enfermería. Las preocupaciones identificadas pueden ofrecer subsidios para la comprensión del universo y de las concepciones pedagógicas de ser profesor en la enfermería.

Palabras clave: Docentes de enfermería. Práctica del docente de enfermería. Enseñanza. 


\section{DINTRODUCTION}

While it is possible to observe changes in the teaching scenario in higher education for nursing, traditionally, graduates perform teaching activities in the absence of any pedagogical training. The training for teaching in nursing is activity that is still on the path to understanding and structuring.

The key element for the development of university teaching is, without a doubt, the professor. Said professor often has his or her identity process rooted in his or her specialty, scientific production or other activities that generate academic merit, ${ }^{(1)}$ without formal demands on their teaching skills inside the classroom or understanding of this universe ${ }^{(2)}$.

University teachers do not usually identify with the teaching, but rather with their professional area. In private schools, it is regarded as a form of wage supplement, given much of the faculty is hired part-time and they maintain professional activities in care giving. In public schools, whose dedication time, is often full, it is also secondary in the sense that centrality is shifted to research activities, and academic merit is a defining factor of teaching status ${ }^{(3)}$.

Studies on what makes up the teacher's knowledge incorporate the most varied perspectives, ranging from behavior ${ }^{(4-5)}$, manner of teaching ${ }^{(6)}$, to other perspectives related to the sociology of the professions, thinking about their structure and working conditions ${ }^{(7-8)}$. With relation to nursing, these studies are still incipient, indicating a vast field of research that endorses the teaching qualification, teaching process and the professional's own training in nursing.

In the context of these studies, various terms have been explored, and concepts, such as the reflective teacher, reflective-practices, teaching knowledge, skills, etc., have been incorporated into the debates ${ }^{(4)}$.

Given the diversity of situations experienced by nursing faculty and duplication of the role of the educators, the question becomes: what was the knowledge produced about teaching in higher education for Nursing? Therefore, the objective of this study was to analyze the knowledge produced about teaching in higher education for nursing.

\section{METHODOLOGY}

For this study we chose an integrative literature review, consisting of six steps: identification of the problem, establishment of inclusion/exclusion criteria (sample selection), definition of the information to be extracted from the selected articles, analysis of the information, interpretation of results and presentation of the review ${ }^{(9)}$.
This investigation began after consultations with the LILACS (Latin American Literature in Health Sciences), SciELO (Scientific Electronic Library Online), BDENF (Nursing Database) and ERIC (Education Resources Information Center) databases (The latter included for being the biggest database on issues related to education in the world), using descriptors and keywords (Chart 1).

To guide this review, the following question was formulated: what was the knowledge produced about teaching in higher education Nursing? The criteria for inclusion of publications in this study were: articles electronically available, in their entirety, on the theme; articles published in Portuguese, Spanish and English, from January 2008 to November 2013, concerning the subject in question. Excluded from this study were editorials, letters, opinion articles, commentaries, essays and preliminary notes, as well as duplicate publications in more than one database, theses, dissertations and manuals.

An analysis and interpretation of the data was performed after translation and reading of the articles, using the following steps: 1) identification of the hypothesis or guiding question - development of a problem by the researcher in a clear and objective manner, then a search using the descriptors or keywords; 2) sample selection determining inclusion or exclusion criteria, when establishing the transparency in order to provide depth, quality and reliability for the selection; 3) categorization of the studies - defined as the extraction of information from articles reviewed in order to summarize and organize the information; 4) evaluation of the studies - critical analysis of the data extracted; 5) discussion and interpretation of the results - comparison and justification of the main results with theoretical knowledge and assessment regarding their applicability; 6) presentation of the integrative review and synthesis of the knowledge-information from each revised article in a succinct and systematized manner, demonstrating the evidence found ${ }^{(9)}$.

Data collection was carried out between the months of January and February 2014. The data extracted was organized, in spreadsheets, in ascending numerical order, in Microsoft Excel 2007, according to: year of publication, title, authors, journal, country of origin of the study, type/ approach of the study and main aspects or results. As for the ethical aspects, copyright and content were respected, with no alterations of them to benefit the review.

\section{QRESULTS}

1,148 articles were identified, which, after being fully read and submitted to the inclusion and exclusion crite- 


\begin{tabular}{|c|c|c|c|c|}
\hline \multirow{3}{*}{ Databases: } & \multicolumn{2}{|c|}{ Keywords } & \multicolumn{2}{|c|}{ Descriptors } \\
\hline & \multicolumn{2}{|c|}{$\begin{array}{l}\text { "teaching in nursing" or "nursing education" and "nursing } \\
\text { teachers" and "teaching knowledge"; } \\
\text { "teaching in nursing" or"nursing education" and "professor } \\
\text { of nursing" and "teaching knowledge"; } \\
\text { "conocimiento de la enseñanza" or "educación em } \\
\text { enfermería" or "enseñanza de la enfermería" and "profesor } \\
\text { de la enfermería" and "conocimiento docente". }\end{array}$} & \multicolumn{2}{|c|}{$\begin{array}{l}\text { "nursing faculty" and "nursing faculty } \\
\text { practices" } \\
\text { "docentes de enfermería" and "práctica del } \\
\text { docente de enfermería" } \\
\text { "faculty nursing" and "nursing faculty } \\
\text { practice" }\end{array}$} \\
\hline & Found & Selected & Found & Selected \\
\hline LILACS & 121 & - & 06 & 02 \\
\hline SCIELO & 893 & 19 & 94 & 05 \\
\hline BDENF & 22 & 04 & 04 & 01 \\
\hline \multirow[t]{5}{*}{ ERIC } & 08 & - & - & - \\
\hline & \multicolumn{2}{|c|}{ Total found: 1044} & \multicolumn{2}{|c|}{ Total found: 104} \\
\hline & \multicolumn{2}{|c|}{ Total selected: 23} & \multicolumn{2}{|c|}{ Total selected: 08} \\
\hline & \multicolumn{4}{|c|}{ Total found: 1148} \\
\hline & \multicolumn{4}{|c|}{ Total selected: 31} \\
\hline
\end{tabular}

Chart 1 - Quantitative (n) of the articles found (E) and selected (S) after integrative review by database. Florianópolis, SC, 2014

Source: Research data, 2014.

ria, resulted in 31. Of the total, 728 did not adhere to the theme, 102 were repeated, 55 were outside the time frame, 106 only had abstracts and 157 consisted of editorials, book reviews, dissertations or theses (Figure 1).

The SCIELO and LILACS databases revealed the highest number of productions found. The lowest number of productions in the BDENF and ERIC bases highlights the paucity of scientific literature on the subject in the area of nursing. With relation to the combination of descriptors, this was not effective for tracking the publications related to the keywords (Chart 1). This result can be attributed to the small number of available descriptors on the subject.

Noteworthy is the number of productions in Brazil, with 14 articles; the UK, US and Australia, each had four articles (Chart 2). Spain, Thailand, China, Chile and Portugal appeared with one article each. As for the year of publication, we perceived numerical expressivity in 2010, with 16 published articles (in the previous year, 2009, four articles were published). In the following years, a gradual reduction in the number of articles is apparent: 2011 six articles appear; 2012, three articles; 2013 two articles. No articles were found for the year 2008 that fit the proposed parameters.

For the evaluation of the articles, we took into account their similarities, with the intention of organizing and summarizing the information in a concise way, analyzing questions that can be used in a critical assessment of the selected studies, such as: the research question, the basis for the research question, structuring and relevance of the research question, the study methodology and adequacy of the subjects to the research question ${ }^{(10)}$.

\section{DISCUSSION}

Based on the materials analyzed, it was possible to identify important issues to be reported on teaching in nursing. The discussion of the results is divided into three main areas arising from the categorization of the planned studies in methodological assumptions of the Integrative Literature Review ${ }^{(10)}$ : Training for faculty, Conflict of roles: being a nurse and being a teacher and Organization of the teaching work.

\section{Training for teachers}

To become a good teacher, it is necessary to understand the needs of the students and the development of attitudes that facilitate learning, making the process enjoyable ${ }^{(11)}$.

The identification of nursing professors is done using practical or experiential knowledge, since they define themselves as classroom professionals who, to teach, require pedagogical training ${ }^{(12-16)}$. 


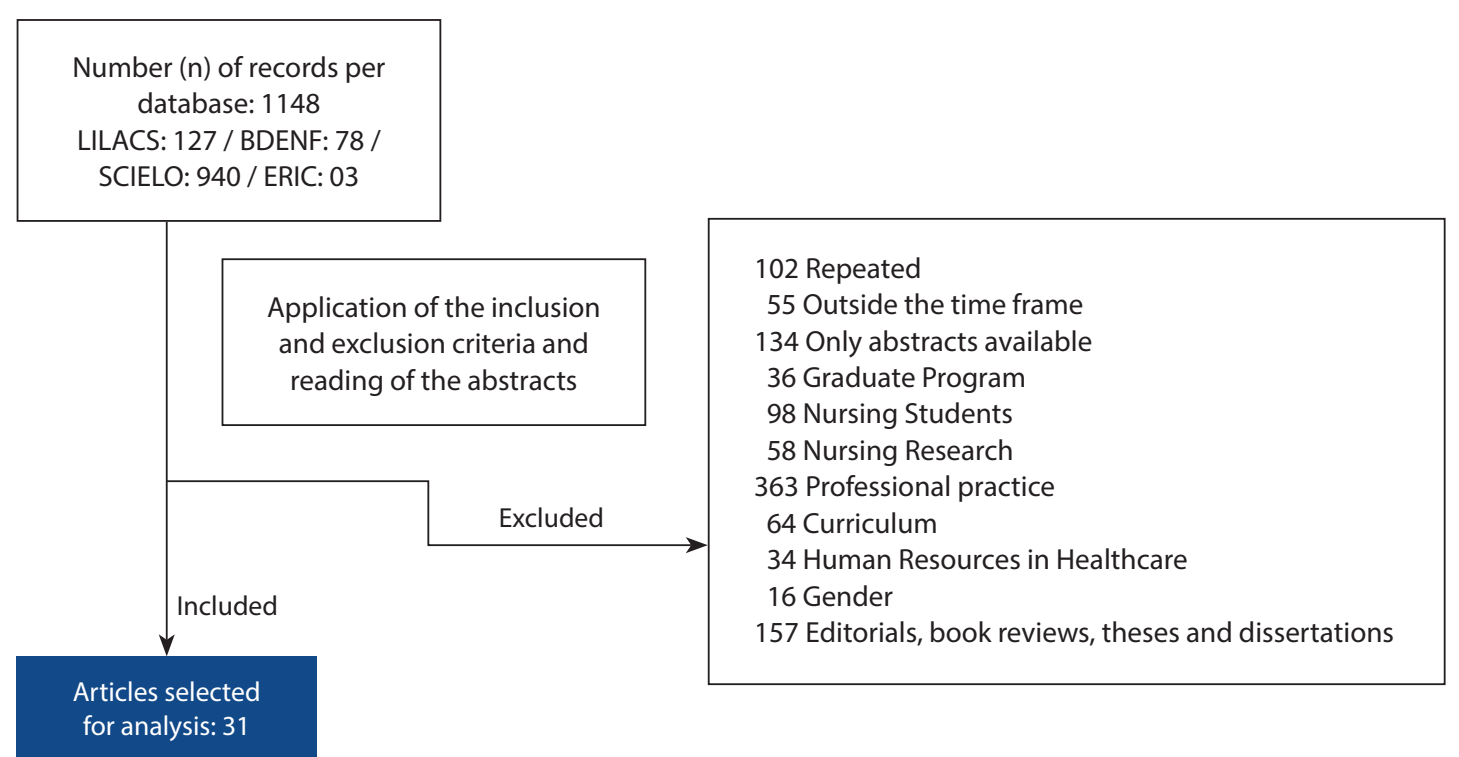

Figure 1 - Diagram of the results from applying the search filter, limits and criteria for inclusion of the articles. Source: Research data, 2014.

There is extensive need for development of new and diverse pedagogies to be used as a basis for teaching ${ }^{(17-19)}$, because individualized methods and techniques are still used, especially for lectures ${ }^{(19-20)}$. The positive appropriation of the individual characteristics of students strengthens the learning process $s^{(12,21-22)}$.

The need to include pedagogical aspects in the initial training of nursing teachers was evident, making continuing education a prerequisite due to the complexity of the content and the teaching ${ }^{(23-24)}$.

The knowledge required for nursing teaching practices and requirements for the development of the teaching act demand: understanding and skillfully transitioning between the specialty and pedagogy; enhancing the experiential knowledge in the creation of a professional identity; deepening the knowledge about the pedagogical practices; maintaining and fostering good relationships with students and worrying about initial and continuing education.

\section{Conflict of roles: being a nurse and being a teacher}

One of the key aspects in the literature with regard to the plurality of activities of nursing teachers. Awareness of this complex approach is needed, as well as the promotion of integration between clinical nurses and nursing teachers in order to facilitate the teaching-learning process ${ }^{(25-27)}$. On the other hand, a traditional vision, not only of education, but also the of the profession, still strongly linked to the biomedical character and charitable actions, is present ${ }^{(15,28)}$.

The non-professionalization or teaching as a secondary career devalues the teaching action and leads to personal and professional dissatisfaction ${ }^{(19.29}$ to 30).

Speeches called maternal emerged predominantly in describing the relationship between teachers and students, particularly in the areas of nursing practice, through gestures of affection, protection, support, guidance and requirement of disciplinary behavior ${ }^{(31-32)}$. The maternal behaviors are close to social representations of the nurse, full of idealizations and stereotypes (mother, religion, sex symbol, aid, no social life due to complete dedication required for the profession, professional subordinate, etc.) ${ }^{(33)}$.

On the other hand, the immaturity of students given the educational proposals are among the aspects that modify the professors' behavior, making them sometimes adopt attitudes perceived as inflexible, related to holding students accountable for delays, breaches of agreements, inattention in the classroom, etc. ${ }^{(34)}$. Affectionate relationships are an important part of the teacher's daily life and constitute the picture in the students' imagination that, when faced with patient care, they feel situations emerge that they experienced in their personal histories, such as illnesses in close relatives.

The teacher should not neglect to understand the emotions and encourage their practice in a loving way, although the "emotionally colorful education" is considered a "rare guest"(35) for teachers whose mindset remains in using 


\begin{tabular}{|c|c|c|c|c|}
\hline Authors & Title & $\begin{array}{l}\text { Type of } \\
\text { Study }\end{array}$ & $\begin{array}{l}\text { Partici- } \\
\text { pants }\end{array}$ & Main points / results \\
\hline $\begin{array}{l}\text { Mafra, Souza, } \\
\text { Fernandes, Correia, } \\
\text { Penna, } 2013 .\end{array}$ & $\begin{array}{l}\text { Political-pedagogical project: } \\
\text { weaknesses and strengths } \\
\text { experienced by university nursing } \\
\text { faculty (Brazil) }\end{array}$ & $\begin{array}{l}\text { Qualitative } \\
\text { Exploratory } \\
\text { Descriptive }\end{array}$ & $\begin{array}{l}\text { Nursing } \\
\text { Teachers }\end{array}$ & $\begin{array}{l}\text { Inflexible attitudes of teachers } \\
\text { and the immaturity of } \\
\text { students facing the proposals. }\end{array}$ \\
\hline $\begin{array}{l}\text { Guimarães, Viana, } \\
\text { Matos, Carvalho, } \\
\text { Baroni, } 2013 .\end{array}$ & $\begin{array}{l}\text { The true value in nursing } \\
\text { education: a phenomenological } \\
\text { study (Brazil) }\end{array}$ & $\begin{array}{l}\text { Qualitative } \\
\text { Phenome- } \\
\text { nology }\end{array}$ & $\begin{array}{l}\text { Nursing } \\
\text { Teachers }\end{array}$ & $\begin{array}{l}\text { The act of educating takes } \\
\text { on a leading role opposite } \\
\text { professional training }\end{array}$ \\
\hline $\begin{array}{l}\text { Bulman, Lathlean, } \\
\text { Gobbi, } 2012 .\end{array}$ & $\begin{array}{l}\text { The concept of reflection in nur- } \\
\text { sing: Qualitative findings on stu- } \\
\text { dent and teacher perspectives (RU) }\end{array}$ & $\begin{array}{l}\text { Qualitative. } \\
\text { Interpretive } \\
\text { ethnography }\end{array}$ & $\begin{array}{l}\text { Academics } \\
\text { and nursing } \\
\text { teachers }\end{array}$ & $\begin{array}{l}\text { Reflective students and } \\
\text { teachers give meaning to the } \\
\text { practice }\end{array}$ \\
\hline $\begin{array}{l}\text { González, Font, } \\
2012 .\end{array}$ & $\begin{array}{l}\text { The nurse teacher. Construction of } \\
\text { a new professional identity (Spain) }\end{array}$ & $\begin{array}{l}\text { Qualitative, } \\
\text { descriptive. } \\
\text { Interpretive }\end{array}$ & $\begin{array}{l}\text { Nursing } \\
\text { Teachers }\end{array}$ & $\begin{array}{l}\text { Nurses face new role as } \\
\text { teachers, seeking to build a } \\
\text { new identity. }\end{array}$ \\
\hline $\begin{array}{l}\text { Ferreira, Pereira, } \\
\text { Xavier, } 2012 .\end{array}$ & $\begin{array}{l}\text { Continuous training and } \\
\text { development of skills in the } \\
\text { professor (Brazil) }\end{array}$ & $\begin{array}{l}\text { Qualitative. } \\
\text { Reflection. }\end{array}$ & - & $\begin{array}{l}\text { Continuing education and } \\
\text { professional development } \\
\text { of the teacher as a personal, } \\
\text { continuous and systematic } \\
\text { process. }\end{array}$ \\
\hline $\begin{array}{l}\text { Backes, Moyá, } \\
\text { Prado, } 2011 .\end{array}$ & $\begin{array}{l}\text { The process of building the } \\
\text { pedagogical knowledge of } \\
\text { university nursing faculty (Brazil) }\end{array}$ & $\begin{array}{l}\text { Qualitative } \\
\text { Exploratory } \\
\text { Descriptive }\end{array}$ & $\begin{array}{l}\text { Nursing } \\
\text { Teachers }\end{array}$ & $\begin{array}{l}\text { Need to consider } \\
\text { pedagogical aspects in the } \\
\text { initial training. }\end{array}$ \\
\hline $\begin{array}{l}\text { Klunklin, } \\
\text { Sawasdisingha, } \\
\text { Viseskul, } \\
\text { Funashima, } \\
\text { Kameoka, Nomoto, } \\
\text { Nakayama, } 2011 .\end{array}$ & $\begin{array}{l}\text { Role model behaviors of nursing } \\
\text { faculty members in Thailand } \\
\text { (Thailand) }\end{array}$ & $\begin{array}{l}\text { Qualitative } \\
\text { Exploratory } \\
\text { Descriptive }\end{array}$ & $\begin{array}{l}\text { Nursing } \\
\text { Teachers }\end{array}$ & $\begin{array}{l}\text { It shows the value of nursing } \\
\text { practices for teaching }\end{array}$ \\
\hline $\begin{array}{l}\text { Gu, While, Chen, } \\
\text { Barriball, Gu, } 2011 .\end{array}$ & $\begin{array}{l}\text { Nurse teachers' working lives: a } \\
\text { questionnaire survey of nursing } \\
\text { schools in Mainland China (China) }\end{array}$ & $\begin{array}{l}\text { Quantitative. } \\
\text { Cross-sec- } \\
\text { tional study }\end{array}$ & $\begin{array}{l}\text { Nursing } \\
\text { Teachers }\end{array}$ & $\begin{array}{l}\text { Dissatisfaction with pay and } \\
\text { opportunities for promotion. }\end{array}$ \\
\hline $\begin{array}{l}\text { Bettancourt, } \\
\text { Muñoz, Merighi, } \\
\text { Santos, } 2011 .\end{array}$ & $\begin{array}{l}\text { Nursing teachers in clinical training } \\
\text { areas: a phenomenological focus } \\
\text { (Chile) }\end{array}$ & $\begin{array}{l}\text { Qualitative. } \\
\text { Phenome- } \\
\text { nology }\end{array}$ & $\begin{array}{l}\text { Nursing } \\
\text { Teachers }\end{array}$ & $\begin{array}{l}\text { The teaching/care integration } \\
\text { is a facilitating element of the } \\
\text { teaching/ } \\
\text { learning process. }\end{array}$ \\
\hline Adams, 2011. & $\begin{array}{l}\text { Exploring dual professional iden- } \\
\text { tities, the role of the nurse tutor in } \\
\text { higher education in the UK: role } \\
\text { complexity and tensions (RU) }\end{array}$ & $\begin{array}{l}\text { Qualitative. } \\
\text { Literature } \\
\text { Review }\end{array}$ & $\begin{array}{l}\text { Articles from } \\
1960-2009\end{array}$ & $\begin{array}{l}\text { Professional status needs. The } \\
\text { tensions and complexities } \\
\text { between the role of educator } \\
\text { and nurse. }\end{array}$ \\
\hline $\begin{array}{l}\text { Jackson, Peters, } \\
\text { Andrew, } \\
\text { Salamonson, } \\
\text { Halcomb, } 2011 .\end{array}$ & $\begin{array}{l}\text { "If you haven't got a PhD, you're } \\
\text { not going to get a job": The PhD as } \\
\text { a hurdle to continuing academic } \\
\text { employment in nursing (Australia) }\end{array}$ & $\begin{array}{l}\text { Qualitative. } \\
\text { Exploratory. } \\
\text { Descriptive. }\end{array}$ & $\begin{array}{l}\text { Temporary } \\
\text { and } \\
\text { permanent } \\
\text { teachers. }\end{array}$ & $\begin{array}{l}\text { PhD perceived as an obstacle } \\
\text { to teaching employability. }\end{array}$ \\
\hline
\end{tabular}

Chart 2 - Publications about teaching in nursing, according to authors, title, country, year, type of study, participants, and summary of the main results, 2008-2013 (continue) 


\begin{tabular}{|c|c|c|c|c|}
\hline $\begin{array}{l}\text { Forbes, Hickey, } \\
\text { White, } 2010 .\end{array}$ & $\begin{array}{l}\text { Adjunct faculty development: } \\
\text { reported needs and innovative } \\
\text { solutions (US) }\end{array}$ & $\begin{array}{l}\text { Qualitative. } \\
\text { Exploratory. } \\
\text { Descriptive. }\end{array}$ & $\begin{array}{l}\text { Nursing } \\
\text { Teachers }\end{array}$ & $\begin{array}{l}\text { The shortage of full-time } \\
\text { teachers can restrain the } \\
\text { necessary expansion of } \\
\text { undergraduate courses. }\end{array}$ \\
\hline $\begin{array}{l}\text { Ribeiro, Ciampone, } \\
2010 .\end{array}$ & $\begin{array}{l}\text { Applicability of complex thought } \\
\text { to the pedagogical practice in } \\
\text { undergraduate nursing education } \\
\text { (Brazil) }\end{array}$ & $\begin{array}{l}\text { Qualitative. } \\
\text { Reflection }\end{array}$ & - & $\begin{array}{l}\text { Questions whether the teach- } \\
\text { er is teaching or people just } \\
\text { learn, in spite of him or her. }\end{array}$ \\
\hline Pereira, 2010. & $\begin{array}{l}\text { Between symbolic domination } \\
\text { and political emancipation in } \\
\text { Higher Education in Nursing } \\
\text { (Brazil) }\end{array}$ & $\begin{array}{l}\text { Qualitative. } \\
\text { Reflection }\end{array}$ & - & $\begin{array}{l}\text { The emergence of formal skills, } \\
\text { ethics and policies depends, in } \\
\text { a large part, on the willingness } \\
\text { and skills of the teachers. }\end{array}$ \\
\hline $\begin{array}{l}\text { Salamonson, } \\
\text { Halcomb, Andrew, } \\
\text { Peters. Jackson, } \\
2010 .\end{array}$ & $\begin{array}{l}\text { A comparative study of assessment } \\
\text { grading and nursing student's: per- } \\
\text { ceptions of quality in sessional and } \\
\text { tenured teachers (Australia) }\end{array}$ & $\begin{array}{l}\text { Quantitative. } \\
\text { Comparative } \\
\text { study }\end{array}$ & $\begin{array}{l}\text { Undergradu- } \\
\text { ate students }\end{array}$ & $\begin{array}{l}\text { Students positively evaluated } \\
\text { temporary teachers } \\
\text { compared to full-time } \\
\text { teachers. }\end{array}$ \\
\hline $\begin{array}{l}\text { Pereira, Chaouchar, } \\
2010 .\end{array}$ & $\begin{array}{l}\text { Identification of new pedagogical } \\
\text { practices on the perception of } \\
\text { nursing program faculty (Brazil) }\end{array}$ & $\begin{array}{l}\text { Qualitative. } \\
\text { Focus group }\end{array}$ & $\begin{array}{l}\text { Nursing } \\
\text { Teachers }\end{array}$ & $\begin{array}{l}\text { Points out changes in the } \\
\text { context of training indicating } \\
\text { that teachers are rethinking } \\
\text { their teaching strategies. }\end{array}$ \\
\hline $\begin{array}{l}\text { Corral-Mulato, } \\
\text { Bueno, Franco, } \\
2010 .\end{array}$ & $\begin{array}{l}\text { Teaching in Nursing: dissatisfaction } \\
\text { and unfavorable indicators (Brazil) }\end{array}$ & $\begin{array}{l}\text { Qualitative. } \\
\text { Exploratory. } \\
\text { Descriptive. }\end{array}$ & $\begin{array}{l}\text { Nursing } \\
\text { Teachers }\end{array}$ & $\begin{array}{l}\text { Excessive activities developed } \\
\text { by educators, excessive } \\
\text { credit hours of lessons and } \\
\text { guidelines, among others. }\end{array}$ \\
\hline $\begin{array}{l}\text { Backes, Marinho, } \\
\text { Costenaro, Nunes, } \\
\text { Rupolo, } 2010 .\end{array}$ & $\begin{array}{l}\text { Rethinking the teaching nurse } \\
\text { being from a complex thinking } \\
\text { perspective (Brazil) }\end{array}$ & $\begin{array}{l}\text { Qualitative. } \\
\text { PCA }\end{array}$ & $\begin{array}{l}\text { Students and } \\
\text { teachers from } \\
\text { a nursing } \\
\text { course }\end{array}$ & $\begin{array}{l}\text { The higher education in nurs- } \\
\text { ing faculty needs to develop } \\
\text { teaching skills, discover and } \\
\text { leverage differences. }\end{array}$ \\
\hline $\begin{array}{l}\text { Madeira, Lima, } \\
2010 .\end{array}$ & $\begin{array}{l}\text { The meaning of teaching practices } \\
\text { in the constitution of knowing } \\
\text { how to teach for the nursing } \\
\text { course professors at the Federal } \\
\text { University of Piauí (Brazil) }\end{array}$ & $\begin{array}{l}\text { Qualitative. } \\
\text { Oral history. }\end{array}$ & $\begin{array}{l}\text { Nursing } \\
\text { Teachers }\end{array}$ & $\begin{array}{l}\text { Need for specific training to } \\
\text { practice teaching. }\end{array}$ \\
\hline $\begin{array}{l}\text { Figueiredo, Afonso, } \\
2010 .\end{array}$ & $\begin{array}{l}\text { Nursing faculty in Portugal: the } \\
\text { reality of teachers in a system of } \\
\text { exclusive dedication (Portugal) }\end{array}$ & $\begin{array}{l}\text { Quantitative. } \\
\text { Documen- } \\
\text { tary }\end{array}$ & $\begin{array}{l}\text { Forms with } \\
\text { information } \\
\text { about the } \\
\text { teachers }\end{array}$ & $\begin{array}{l}\text { Need for individual } \\
\text { building of the training } \\
\text { with repercussions to the } \\
\text { professional group. }\end{array}$ \\
\hline $\begin{array}{l}\text { Corral-Mulato, } \\
2010 .\end{array}$ & $\begin{array}{l}\text { Traditional nursing, present and } \\
\text { future: the view of the nursing } \\
\text { faculty (Brazil) }\end{array}$ & $\begin{array}{l}\text { Quali-quanti- } \\
\text { tative. }\end{array}$ & $\begin{array}{l}\text { Nursing } \\
\text { Teachers }\end{array}$ & $\begin{array}{l}\text { The nursing faculty has a } \\
\text { traditional view of teaching } \\
\text { and nursing, linked to charity } \\
\text { and to the biomedical model. }\end{array}$ \\
\hline $\begin{array}{l}\text { Rocha, Pereira } \\
\text { Amorim, Andrade, } \\
\text { Dantas, } 2010 .\end{array}$ & $\begin{array}{l}\text { Teaching methods and techniques } \\
\text { used by higher education nursing } \\
\text { faculty (Brazil) }\end{array}$ & $\begin{array}{l}\text { Qualitative. } \\
\text { Exploratory. } \\
\text { Descriptive. }\end{array}$ & $\begin{array}{l}\text { Nursing } \\
\text { Teachers }\end{array}$ & $\begin{array}{l}\text { The teachers investigated } \\
\text { used individualized methods } \\
\text { and techniques, highlighted } \\
\text { in the lectures. }\end{array}$ \\
\hline
\end{tabular}

Chart 2 - Publications about teaching in nursing, according to authors, title, country, year, type of study, participants, and summary of the main results, 2008-2013 (continue) 


\begin{tabular}{|c|c|c|c|c|}
\hline Prado, Leite, 2010. & $\begin{array}{l}\text { Understanding the intentions of } \\
\text { the actions of a multidisciplinary } \\
\text { faculty in an undergraduate } \\
\text { nursing course (Brazil) }\end{array}$ & $\begin{array}{l}\text { Qualitative } \\
\text { Phenome- } \\
\text { nology }\end{array}$ & $\begin{array}{l}\text { Nursing } \\
\text { Teachers }\end{array}$ & $\begin{array}{l}\text { Concern of teachers } \\
\text { with their didactic and } \\
\text { pedagogical training. }\end{array}$ \\
\hline Smith, Allan, 2010. & $\begin{array}{l}\text { "We should be able to bear our } \\
\text { patients in our teaching in some } \\
\text { way": Theoretical perspectives on } \\
\text { how nurse teachers manage their } \\
\text { emotions to negotiate the split } \\
\text { between education and caring } \\
\text { practice (UK) }\end{array}$ & $\begin{array}{l}\text { Qualitative. } \\
\text { Exploratory. } \\
\text { Descriptive }\end{array}$ & $\begin{array}{l}\text { Nursing } \\
\text { Teachers }\end{array}$ & $\begin{array}{l}\text { Nurses who are professors } \\
\text { distanced themselves from } \\
\text { patients. Uncertainty about } \\
\text { the role of the teacher. }\end{array}$ \\
\hline Allan, Smith, 2010 & $\begin{array}{l}\text { Are pedagogies used in nurse } \\
\text { education research evident in } \\
\text { practice? (United Kingdom) }\end{array}$ & Reflection & - & $\begin{array}{l}\text { The lack of knowledge } \\
\text { about the pedagogical } \\
\text { practices and forms of } \\
\text { learning compromises the } \\
\text { performance of nursing } \\
\text { teachers. }\end{array}$ \\
\hline Forbes, 2010. & $\begin{array}{l}\text { Clinical teachers'approaches to } \\
\text { nursing (Australia) }\end{array}$ & $\begin{array}{l}\text { Qualitative. } \\
\text { Phenome- } \\
\text { nology }\end{array}$ & $\begin{array}{l}\text { Clinical } \\
\text { nurses that } \\
\text { are currently } \\
\text { teachers }\end{array}$ & $\begin{array}{l}\text { Teachers focused either on } \\
\text { the patient, or on research. }\end{array}$ \\
\hline $\begin{array}{l}\text { Halcomb, } \\
\text { Andrews, Peters, } \\
\text { Salamonson, } \\
\text { Jackson, } 2010 .\end{array}$ & $\begin{array}{l}\text { Casualization of the teaching } \\
\text { workforce: Implications for nursing } \\
\text { education (USA) }\end{array}$ & $\begin{array}{l}\text { Qualitative. } \\
\text { Integrative } \\
\text { Review }\end{array}$ & - & $\begin{array}{l}\text { The use of temporary } \\
\text { teachers contributes to the } \\
\text { precariousness of higher } \\
\text { education. }\end{array}$ \\
\hline $\begin{array}{l}\text { Andrew, Halcomb, } \\
\text { Jackson, Peters, } \\
\text { Salamonson, } 2009 .\end{array}$ & $\begin{array}{l}\text { Sessional teachers in a BN } \\
\text { program: Bridging the divide or } \\
\text { widening the gap? (USA) }\end{array}$ & $\begin{array}{l}\text { Quali- } \\
\text { Quantitative. }\end{array}$ & $\begin{array}{l}\text { Temporary } \\
\text { professors }\end{array}$ & $\begin{array}{l}\text { The casualization of } \\
\text { academic work has resulted } \\
\text { in an increase of temporary } \\
\text { teachers, which in turn, is } \\
\text { believed to enhance the } \\
\text { experiential training. }\end{array}$ \\
\hline $\begin{array}{l}\text { Ferreira, Fernandes, } \\
\text { Prado, Baptista, } \\
\text { Freitas, Bonini, } \\
\text { 2009. }\end{array}$ & $\begin{array}{l}\text { Pleasure and suffering in the nurse } \\
\text { teaching work process (Brazil) }\end{array}$ & $\begin{array}{l}\text { Qualitative } \\
\text { Exploratory } \\
\text { and descrip- } \\
\text { tive. }\end{array}$ & $\begin{array}{l}\text { Private HEl } \\
\text { professors }\end{array}$ & $\begin{array}{l}\text { Feelings of pleasure and } \\
\text { suffering resulting from } \\
\text { ambiguous relationships in } \\
\text { the faculty's work process. }\end{array}$ \\
\hline $\begin{array}{l}\text { Mskenna, Wellard, } \\
2009 .\end{array}$ & $\begin{array}{l}\text { Mothering: an unacknowledged } \\
\text { aspect of undergraduate } \\
\text { clinical teachers' work in nursing } \\
\text { (Australia) }\end{array}$ & $\begin{array}{l}\text { Qualitative. } \\
\text { Exploratory } \\
\text { Descriptive }\end{array}$ & $\begin{array}{l}\text { Nursing } \\
\text { Teachers }\end{array}$ & $\begin{array}{l}\text { Maternal speeches appeared } \\
\text { predominantly in describing } \\
\text { the relationships between } \\
\text { teachers and students }\end{array}$ \\
\hline $\begin{array}{l}\text { Johnson-Farmer, } \\
\text { Frenn, } 2009 .\end{array}$ & $\begin{array}{l}\text { Teaching excellence: what great } \\
\text { teachers teach us (USA) }\end{array}$ & $\begin{array}{l}\text { Qualitative. } \\
\text { Exploratory. } \\
\text { Descriptive }\end{array}$ & $\begin{array}{l}\text { Nursing } \\
\text { Teachers }\end{array}$ & $\begin{array}{l}\text { To become a good teacher, } \\
\text { it is necessary to understand } \\
\text { the student's needs. }\end{array}$ \\
\hline
\end{tabular}

Chart 2 - Publications about teaching in nursing, according to authors, title, country, year, type of study, participants, and summary of the main results, 2008-2013 (conclusion)

Source: Research data, 2014. 
the logic of specialties and the biomedical model. Thus, the idealizations present in relationships between teachers and students turn out to be significant in the nursing education universe.

In scenarios where there is exclusive dedication to teaching, another factor present is the distancing of part of the professors from care and, consequently, patients ${ }^{(15,25,35)}$. The relationship established with them can range from indifference, to hostility to affection, and helps build the idea that the students' imagine about care.

On the other hand, in scenarios where exclusive dedication to teaching is not present, usually in private or public universities where there is no unrestricted requirement for exclusive dedication, the approximation to nursing care practice becomes a valued factor of the professor by the students.

\section{Organization of teaching work}

The increase in the number of temporary teachers or substitutes, especially in public universities, results in precariousness of the job. They believed that contribute to the process of teaching and learning, as they bring reality to teaching, favoring experimental knowledge ${ }^{(36-37)}$.

With regard to the daily work life, teachers point out feelings of pleasure and suffering and show the conditions and the organization of work as elements that enhance these feeling ${ }^{(38-39)}$.

Some of the issues that contribute negatively to the teaching work include the excess of activities; requirements of funding agencies; the constant need for updating; meetings; excessive class workload, scientific research guidelines; preparation of evaluations; participation in examiner and commission panels; publishing papers; among others ${ }^{(14.39)}$.

The shortage of nursing faculty that works on a fulltime basis in European countries has contributed to the apprehensive expansion of undergraduate courses ${ }^{(25,40-41)}$. On the other hand, in Brazil, this reality presents itself differently, since the realities are different. Between 1999 and 2011, the growth of undergraduate programs in the country was around $754 \%$, with a significant advantage of private courses, where there is no full time job requirement ${ }^{(42)}$.

\section{a FINAL CONSIDERATIONS}

By analyzing the knowledge produced about teaching in nursing we can see that it is situated between understanding: the elements that make up the professorial universe through a lack of teacher training; the existence of conflicts between being a teacher and being a nurse, with particular praise for experiential learning; and organization of the teaching work, whose difficulties can be attributed to the absence of a pedagogical understanding and external factors such as public policy related to hiring and labor. Current prospects for training place the reflective processes at the center of the teaching exercise. Despite the limitations present in this study, resulting, mainly, from the low number of productions found, the evidence cited may be useful for discussions about the topic, as well as the development of future research that addresses the identity process of nursing teachers, knowledge necessary for teaching and the feelings of the teachers, among others, which may ratify or refute the findings.

\section{REFERENCES}

1. Zabalza MA. 0 ensino universitário: seu cenário e seus protagonistas. Porto Alegre: Artmed; 2004.

2. Schön DA. Educando o profissional reflexivo: um novo design para o ensino e a aprendizagem. Porto Alegre: Artmed; 2000.

3. Pimenta SG, Anastasiou LGC. Docência no ensino superior. 3. ed. São Paulo: Cortez; 2008.

4. Alves WF. A formação de professores e as teorias do saber docente: contextos, dúvidas e desafios. Educ Pesqui. 2007;33(2):263-80.

5. Gubert E, Prado ML. Desafios na prática pedagógica na educação profissional em enfermagem. Rev Eletron Enferm [Internet]. 2011 [cited in 2014 jan. 16];13(2):285-95. Available at: http://www.fen.ufg.br/revista/v13/n2/ v13n2a15.htm

6. Machado C, Fernandes CH. Saberes docentes em ruptura: uma análise das concepções sobre a docência de professores em formação. Rev Ibero-am Estud Educ. 2013;8(2):421-38.

7. Borges CMF, Tardif M. Dossiê: os saberes dos docentes e sua formação. Educ Soc. 2001;22(74):11-26.

8. Rodrigues MTP, Sobrinho JACM. Obstáculos didáticos no cotidiano da prática pedagógica do enfermeiro professor. Rev Bras Enferm. 2008;61(4):435-40.

9. Ganong LH. Integrative review of nursing research. Res Nurs Health. 1987;10(1):1-11.

10. Mendes KDS, Silveira RCCP, Galvão CM. Revisão integrativa: método de pesquisa para a incorporação de evidências na saúde e na enfermagem. Texto Contexto Enferm. 2008;17(4):758-64.

11. Halcomb EJ, Andrew S, Peters K, Salamonson Y, Jackson D. Casualisation of the teaching workforce: Implications for nursing education. Nurse Educ Today. 2010;30(6):528-32.

12. Backes DS, Marinho M, Costenaro RS, Nunes S, Rupolo I. Repensando o ser enfermeiro docente na perspectiva do pensamento complexo. Rev Bras Enferm. 2010;63(3):421-6.

13. Madeira MZA, Lima MGSB. 0 significado da prática docente na constituição do saber ensinar das professoras do curso de enfermagem da Universidade Federal do Piauí. Texto Contexto Enferm. 2010;19(1):70-7.

14. Corral-Mulato S. Enfermagem tradicional, atual e do futuro: a visão de docentes de enfermagem. Rev Enferm UERJ. 2010;18(4):572-7. 
15. Salamonson Y, Halcomb EJ, Andrew S, Peters K, Jackson D. A comparative study of assessment grading and nursing student's: perceptions of quality in sessional and tenured teachers. J Nurs Scholarsh. 2010;42(4):423-9.

16. Bettancourt L, Muñoz LA, Merighi MAB, Santos MF. 0 docente de enfermagem nos campos de prática clínica: um enfoque fenomenológico. Rev Latino-Am Enfermagem. 2011;19(5):1197-204.

17. Bulman C, Lathlean J, Gobbi M. The concept of reflection in nursing: qualitative findings on student and teacher perspectives. Nurse Educ Today. 2012;32(5):8-13.

18. Guimarães GL, Viana LO, Matos SS, Carvalho DV, Baroni FCL. 0 valor verdade no ensino da enfermagem: um estudo fenomenológico. Rev Gaúcha Enferm. 2013;34(1):133-9.

19. Allan H, Smith P. Are pedagogies used in nurse education research evident in practice? Nurse Educ Today. 2010;30:476-9.

20. Rocha JA, Pereira KS, Amorim FDB, Andrade MVM, Dantas CC. Métodos e técnicas de ensino utilizado por docentes de enfermagem do ensino superior. $R$ Pesqui Cuid Fundam. (Online) [Internet]. 2010 [cited in 16 jan. 2014];2:81720. Available at: http://www.seer.unirio.br/index.php/cuidadofundamental/ article/view/1143/pdf_291

21. Pereira WR, Chaouchar SH. Identificação de novas práticas pedagógicas na percepção dos docentes de um curso de enfermagem. Ciênc Cuid Saúde. 2010;9(1):99-106.

22. Ribeiro MRR, Ciampone MHT. Aplicabilidade do pensamento complexo à prática pedagógica no ensino de graduação em enfermagem. Ciênc Cuid Saúde. 2010;9(1):173-8.

23. Backes VMS, Moyá JLM, Prado ML. Processo de construção do conhecimento pedagógico do docente universitário de enfermagem. Rev Latino-Am Enfermagem. 2011;19(2):421-8.

24. Pereira WR. Entre a dominação simbólica e a emancipação política no ensino superior em enfermagem. Rev Esc Enferm USP. 2011;45(4):981-8.

25. Forbes H. Clinical teachers'approaches to nursing. J Clin Nurs. 2010;19(5):78593.

26. Ferreira RMF, Pereira MMN, Xavier SMM. A formação contínua e o desenvolvimento de competências no professor. Rev Enferm UFPE on line [Internet]. 2012 [cited in 16 jan. 2014];6(9):2298-306. Available at: http://www.revista.ufpe. br/revistaenfermagem/index.php/revista/article/view/2735/pdf_1502

27. Klunklin A, Sawasdisingha P, Viseskul N, Funashima N, Kameoka T, Nomoto Y, et al. Role model behaviors of nursing faculty members in Thailand. Nurs Health Sci. 2011;13(1):84-7.

28. Corral-Mulato S, Bueno SMV, Franco DM. Docência em enfermagem: insatisfações e indicadores desfavoráveis. Acta Paul Enferm. 2010;23(6):769-74.

\section{Author's address:}

Daniele Delacanal Lazzari

Universidade Federal de Santa Catarina

Centro de Ciências da Saúde

Departamento de Enfermagem, bloco H, $4^{\circ}$ andar, sala 414

88040-900 Florianópolis - SC

E-mail: danielelazza@gmail.com
29. Prado C, Leite MMJ. Compreendendo as intenções das ações de um corpo docente multiprofissional em um curso de graduação em enfermagem. Rev Bras Enferm. 2010;63(4):548-54.

30. González MA, Font CM. The nurse teacher: construction of a new professional identity. Invest Educ Enferm. 2012;30(3):398-405.

31. McKenna L, Wellard S. Mothering: an unacknowledged aspect of undergraduate clinical teachers work in nursing. Adv Health Sci Educ Theory Pract. 2009;14(2):275-85.

32. Smith P, Allan H. "We should be able to bear our patients in our teaching in some way": theoretical perspectives on how nurse teachers manage their emotions to negotiate the split between education and caring practice. Nurse Educ Today. 2010;30:218-23.

33. Júnior MAF. Os reflexos da formação inicial na atuação dos professores enfermeiros. Rev Bras Enferm. 2008;61(6):866-71.

34. Mafra IF, Souza NVDO, Fernandes MC, Correia LM, Penna LHG. Projeto político-pedagógico: fragilidades e potencialidades vividas por docentes universitários de enfermagem. Rev Enferm UERJ;21(3):361-5.

35. Vygotsky LS. A construção do pensamento e da linguagem. São Paulo: Martins Fontes; 2001.

36. Andrew S, Halcomb EJ, Jackson D, Peters K, Salamonson Y. Sessional teachers in a BN program: bridging the divide or widening the gap? Nurse Educ Today. 2010;30(5):453-7.

37. Jackson, D.; Peters, K.; Andrew, S.; Salamonson, Y.; Halcomb, E.J. "If you haven't got a PhD, you're not going to get a job": the PhD as a hurdle to continuing academic employment in nursing. Nurse Educ Today. 2011;31(4):340-4.

38. Ferreira EM, Fernandes MFP, Prado C, Baptista PCP, Freitas GF, Bonini BB. Prazer e sofrimento no processo do trabalho do enfermeiro docente. Rev Esc Enferm USP. 2009;43(2):1292-6.

39. Figueiredo AS, Afonso N. Docentes de enfermagem em Portugal: a realidade dos professores em regime de dedicação exclusiva. Cad Saúde. 2010;3(2):53-64.

40. Adams R. Exploring dual professional identities, the role of the nurse tutor in higher education in the UK: role complexity and tensions. J Adv Nurs. 2011;67(4):884-92

41. Gu L, While AE, Chen G, Barriball KL, Gu RNS. Nurse teachers' working lives: a questionnaire survey of nursing schools in Mainland China. Int Nurs Rev. 2011;58(4):505-11.

42. Fernandes JD, Teixeira GAS, Silva MG, Florêncio RMS, Silva RM0, Santa Rosa DO. Expansão da educação superior no Brasil: ampliação dos cursos de graduação em enfermagem. Rev Latino-Am Enfermagem [Internet]. 2013 [cited in 18 mar. 2015];21(3):[08 telas]. Available at: http://www.scielo.br/pdf/rlae/v21n3/ pt_0104-1169-rlae-21-03-0670.pdf
Received: 18.08.2014

Approved: 09.06.2015 